\title{
Çağdaş Çocuk Kitaplarında Yer Alan Aile Büyüklerinin Sunuluş Biçimleri Üzerine Bir Araştırma*
}

\author{
Ayşegül GÖKSEL** \\ Ali Fuat ARICI***
}

\section{Öz}

Bir ulusun varlığını devam ettirebilmesinin teminatlarından sayılan aile, zamanla farklı biçimlere evrilmiştir. Bu süreç, büyük ebeveyn-torun ilişkisinde sancılı değişimleri beraberinde getirmiştir. Çekirdek aileye sıkıştırılan çocuk, aile büyüklerinin tecrübe ve sevgisiyle büyüme olanağından mahrum bırakılmıştır. Çocuğun gelişiminde sağlıklı kurulan büyük ebeveyn-torun ilişkisine ihtiyaç vardır. Modern dünyanın bu ilişkiye izin vermediği durumlarda mevcut boşluğu doldurmak için çocuk edebiyatına da mühim görevler düşmektedir. Nitel araştırma desenlerinden iç içe geçmiş tek durum deseniyle gerçekleştirilen bu araştırmada çağdaş çocuk kitaplarında yer alan aile büyüklerinin sunuluş biçimleri ele alınmıştır. Çalışma kapsamında içerisinde büyük ebeveyn-torun ilişkisini ve aktarımını ihtiva eden ölçüt örnekleme ile araştırma nesnesi olarak belirlenen 15 çocuk kitabı (Yeşilcik, Gemici Dedem, Dedemi Kimseye Kaptırmam, Dedem Benim En İyi Arkadaşım, Yasemin ve Lavanta, Çetin Ceviz, Dedemin Ayçiçeği Tarlası, Dedemin Uçan Dairesi, Taşkafa, Dedemin Bakkalı, Dedem Eve Dönüyor, Dünyanın En Talihli Vapuru, Ninemin Yemekleri Dedemin Oyuncakları, Anneannem Gelin Oldu, Anneannemin Güzel Çiçekleri) doküman olarak kabul edilmiş ve analiz sürecinde doküman incelemesinden yararlanılmıştır. İçerik analizi tekniği ile eserlerde yer alan dede/nine figürlerinin sunuluş biçimleri (44 unsuru kapsayan 19 kategori) tespit edilmiş, kategorileştirilen mevcut veriler betimsel analiz ile yorumlanmıştır. Araştırma sonucunda, incelenen eserlerde en fazla "günlük yaşam" ana kategorisine yer verildiği belirlenmiştir. Kitaplar içinde en çok rastlanan unsur" kişiler arası olumlu iletişim"dir. Eserlerde "vatan sevgisi” kategorisine hiç yer verilmediği saptanmıştır. Toplam unsur miktarının en fazla olduğu eser "Ninemin Yemekleri Dedemin Oyuncakları”, unsur çeşitliliğine en fazla yer verilen eser ise "Dedemin Uçan Dairesi" dir. Her iki kategoride de en az unsur tespit edilen eser, "Çetin Ceviz"dir. 14 kitapta büyük ebeveyn-torun arasında olumlu iletişime rastlanmıştır. Elde edilen bulgular doğrultusunda nine ve dede figürlerinin sunuluş biçimleri unsurlarının çocuk kitaplarında dengeli dağılım göstermediği, belirli kategorilere odaklanıldığı sonucuna varılmıştır. Çocuk kitaplarında yer alan nine ve dede karakterlerinin sunuluş biçimlerinin çocuğun gelişimine, nesiller arası aktarıma katkı sağlayacak biçimde zenginleştirilmesi önerilmiştir.

Anahtar Kelimeler: Çocuk edebiyatı, çocuk kitapları, aile büyükleri, nine, dede, çocuk.

\footnotetext{
* Bu makale "Çağdaş Çocuk Kitaplarında Aile Büyüklerinin Sunuluş Biçimleri” isimli yüksek lisans tezinden üretilmiştir.

** Y1ldız Teknik Üniversitesi SBE Türkçe Eğitimi Doktora Öğrencisi, İstanbul, Türkiye.

Elmek: aysegul.goksel@hotmail.com

https://orcid.org/0000-0003-0635-956X.

Prof. Dr., Yıldız Teknik Üniversitesi, Türkçe ve Sosyal Bilimler Eğitimi Bölümü, İstanbul, Türkiye.

Elmek: afaturkey@hotmail.com

https://orcid.org/0000-0003-0980-0824.
} 


\title{
A Research on The Presentations of Family Elders in Contemporary Children's Books
}

\begin{abstract}
Considered as a guarantee for a nation to survive, the family evolved over time to different forms. This process brought about painful changes in the great parent-grandchild relationship. Compressed into the nuclear family, the child is deprived of the opportunity to grow with the experience and love of the family elders. In the child's development, there is a need for a great parent-grandchild relationship. In cases where the modern world does not allow this relationship, there are also important duties for children's literature to fill the current gap. In this study, which is carried out with a case study, which is one of the qualitative research patterns, the presentation styles of the family elders in contemporary children's books are discussed. Within the scope of the study, 15 children's books determined as a research object and a criterion sampling containing the grandparent-grandchild relationship and transfer were accepted as documents, and document analysis was used in the analysis process. With the content analysis technique, the presentation styles of the grandfather / granny figures in the works (19 categories including 44 elements) were determined, and the available data were interpreted with descriptive analysis. As a result of the research, it has been determined that the main category of "daily life" is mostly included in the studied works. The most common element among the books is "positive interpersonal communication". It is determined that there is no place in the category of "love of homeland" in the works. "Ninemin Yemekleri Dedemin Oyuncakları" is the work with the highest total amount of elements, and "Dedemin Uçan Dairesi" is the most widely used work. The least identified element in both categories is "Çetin Ceviz". Positive communication was found between grandparents and grandchildren in 14 books. In line with the findings obtained, it was concluded that the elements of presentation of grandmother and grandfather figures do not show a balanced distribution in children's books and focus on certain categories. It is suggested that the presentation of the grandmother and grandfather characters in the children's books should be enriched in a way to contribute to the development of the child and intergenerational transfer.
\end{abstract}

Keywords: Children's literature, children's books, family elders, grandmother, grandfather, child 


\section{Extended Summary \\ Introduction}

With the industrial revolution in the world, migration from village to city has increased and this shocking change has deeply affected the family institution. Large families in which several generations live together have been replaced by nuclear families consisting of mothers, fathers and unmarried children. The inclusion of mothers of nuclear families in the working life, which is frequently encountered today, has increased the need for assistance in the care and education of children. The issue of "who will take care of the child" poses a big problem for working parents (Utaş Akhan and Batmaz). Since child education is not an issue that can be taken lightly, the child must be delivered to reliable hands during the long hours parents spend outside home.

Childcare support is very important in raising new generations (Poduval - Poduval, 2009). Grandparents who are accepted as important members of the family system (Lussier-Deater-Deckard et al. 2002) and who play a parent-like role in child education (Chu-Xie et al. 2011) are seen as the most trusted sources of assistance for parents (Greenblat-Ochiltree, 1993; NICHD, 1996) with their experience, knowledge, moral values and intense love for their grandchildren. They support the social development of their grandchildren with the communication styles they establish with them, their personality development by boosting their self-confidence, self-esteem, self-efficacy and so on., their language and mental development with stories, riddles, lullabies and games, their moral development with the rules they set and rewards and punishments they use, and their emotional development with the love and compassion they show (AltanTarhan, 2018: 28). It also plays an important role in the transfer of basic national values such as national culture, language awareness and historical consciousness. Representing other times, these two different generations meet on a plane.

Today, the amount and duration of intergenerational interaction are gradually decreasing (Hazer, 2011). According to the British Social Attitudes (BSA) survey, 32 percent of grandparents see their grandchildren less than once 
a month (Dench-Ogg, 2002). However, there is a need for a grandparent-grandchild relationship established in the development and education of the child. The question of what will happen to children who cannot spend enough time with their grandparents and grow up without them, and how to fill this gap is a problem that occupies minds.

In order for children not to be deprived of the transfer / sharing process between generations and to be cultured correctly, there is a need for children's literature products with well-formed grandmother and grandfather characters. "The children's book has the potential to affect cultural norms and attitudes about family elders (Beland-Milly, 2001), a statement linking an adult in a particular society and a child lacking the knowledge and experience and emotional maturity of adults belonging to the same community, a historical communication" (Soriano, 1979: 21). Whether the grandmother and grandfather characters in the children's books written by today's authors are created to meet the child's development needs, and how intergenerational transfer takes place is an issue to be examined.

The number of research and children's books on the grandparents-grandchildren relationship and transfer is limited. In the literature, there is no research that examines the presentation styles of family elders. The studies of grandparents and grandchildren are mostly found in studies in the fields of sociology, psychology and social services.

Grandparents-grandchildren researches abroad focused on grandparentsgrandchildren relationship (Dunifon-Bajracharya, 2012) and depictions of grandparents in children's books (Janelli, 1988; Fenwick-Morrison, 2001). Studies on large families in Turkey has focused largely on the opinions of grandparents and grandchildren about each other (Arpaci-Single, 2013; Demiriz-Arpac1, 2016).

This research is one of the first studies on the presentation of family elders in contemporary children's books. At the same time, the limited number of studies on family elders, grandparents, or the elderly in areas such as children's literature, sociology, and education makes this study important. The aim of the study is to examine the presentation styles of family elders in contemporary children's books. 


\section{Method}

This research is "a structured case study in a qualitative pattern". In the study, the presentation styles of grandparents and grandparents in contemporary children's books were examined through case study and the dimensions of the grandparent-grandchild relationship and transference were analyzed.

Fifteen children's books, which are based on the relationship and transfer of grandparents and grandchildren, have a decisive role in grandmother and grandfather characters, are in the category of contemporary children's books and written by Turkish authors.

\section{Result}

In 15 contemporary children's books analyzed in the context of 19 main categories and 44 sub-units, the titles "Dedemin Uçan Dairesi" and "Ninemin Yemekleri Dedemin Oyuncakları" have the most items in terms of total element ratio in terms of variety of elements. It was concluded that the communication between grandparents and grandchildren was mostly positive (14 works). However, it has been determined that the ways in which grandparents and grandchildren are presented are far from diverse, there is clustering in certain areas, and there are few (historical consciousness) transfers in some categories, and that there is no (love of homeland) transfers, and the current transfers are not of sufficient quantity and quality. It was. In the works, the transfer of grandfather and granny characters did not show a balanced distribution and focusing on several areas was a deficiency. 


\section{Giriş}

Dünyada endüstri devrimi ile birlikte köyden kente göçler artmış ve bu sarsıcı değişim aile kurumunu derinden etkilemiştir. Birkaç kuşağın bir arada yaşadığ 1 geniş aileler yerlerini anne, baba ve evlenmemiş çocuklardan oluşan çekirdek ailelere bırakmıştır. Günümüzde sıkça rastlanan çekirdek ailede annelerin de çalışma hayatına dâhil olması, çocukların bakımı ve eğitiminde yardım alma ihtiyacını artırmıştır. Çalışan ebeveynler için "çocukla kimin ilgileneceğì" hususu büyük sorun teşkil etmektedir (Utaş Akhan ve Batmaz). Çocuk eğitimi hafife al1nabilecek bir konu olmadığından anne babanın ev dışında geçirdiği uzun saatler boyunca çocuğun güvenilir ellere teslim edilmesi gerekmektedir.

Yeni nesillerin yetiştirilmesinde çocuk bakımı desteği çok önemlidir (Poduval - Poduval, 2009). Aile sisteminin önemli üyeleri (Lussier-Deater-Deckard vd. 2002) olarak kabul edilen ve çocuk eğitiminde ebeveyn benzeri bir rol oynayan (Chu-Xie vd. 2011) dedeler ve nineler; sahip oldukları tecrübe, bilgi, ahlaki değer ve torunlarına duydukları yoğun sevgiyle anne ve babalar için en güvenilen (Greenblat-Ochiltree, 1993; NICHD, 1996) yardım kaynakları olarak görülmüşlerdir.

Aile büyükleri "torunları ile kurdukları iletişim tarzları ve koydukları kurallarla sosyal gelişimi; çocuğa kazandırdıkları özgüven, özsaygı, öz yeterlilik vb. ile kişilik gelişimini; hikâye, bilmece, ninni ve oyunlarla dil ve zihin gelişimini; uyguladıkları ödül ve ceza ile ahlak gelişimini; gösterdikleri sevgi, şefkat ile duygu gelişimini destekler.” (Altan-Tarhan, 2018: 28). Aynı zamanda büyük ebeveynler, "aile içinde gerçekleşen iletişimlerde sözel edebiyatın ürünleri, âdetler, görenekler, ahlaki ve din[î] bilgiler" (Canatan, 2008:67) gibi birikimlerin, millî ve manevi kültür, dil bilinci ve tarih şuuru gibi temel değerlerin aktarılmasında da önemli rol oynar. Başka zamanların temsili olan bu iki farklı nesil ortak bir düzlemde buluşur. "Torunların temsil ettiği oluşmakta olan hayat ile büyükanne ve büyükbabaların temsil ettiği geçip gitmekte olan hayat arasındaki çember kapanır" (Schmid, 2018: 60). 
Günümüzde kuşaklar arası etkileşimin miktarı ve süresi giderek azalmaktadır (Hazer, 2011). İngiliz Sosyal Tutumları (BSA) araştırmasına göre büyükanne ve büyükbabaların \%32〉si torunlarını ayda bir kereden az görmektedir (Dench-Ogg, 2002). Aile büyüklerinden ayrı büyüyen çocuklar sosyal yaşamda çeşitli iletişim sorunları yaşamakta ve empatik becerilerini tam olarak geliştirememektedir (Engin, 2013). Oysa çocuğun gelişimi ve eğitiminde sağlıklı kurulan büyük ebeveyn-torun ilişkisine ihtiyaç vardır. Büyük ebeveynleriyle yeterince zaman geçiremeyen, onlardan yoksun büyüyen çocuklara ne olacağı, bu boşluğun nasıl doldurulacağı sorusu ise kafaları meşgul eden bir problemdir.

Çocuk edebiyatı, çocuk gelişimi ve eğitiminde mühim bir yere sahiptir. Çocuk, hayatı edebiyat vasıtasıyla keşfeder (Alver, 2005), okuduğu kitaplardaki kahramanlarla özdeşim kurar, o kahramanların etkisinde kalır. Bu kahramanlar ve onların niteliklerinden yararlanarak yeni yaşantılar kazanır (Sever, 2008: 77). Yani çocuklara yönelik eserlerdeki kahraman kadroları son derece önemlidir (Geçgel-Ak, 2007) ve iyi yapılandırılmış kahramanlar çocuğun tekâmülüne katk1 sağlayabilir. Bu bakımdan çocukların eserlerdeki kahramanlarla etkileşim içine girerek doğru özdeşim kurabilmeleri, kuşaklar arası aktarım/paylaşım sürecinden mahrum kalmamaları, ve kültürlenebilmeleri için iyi kurgulanmış nine ve dede karakterleriyle oluşturulmuş çocuk kitaplarıyla karşılaştırılmaları gerekmektedir.

"Çocuk kitabı, aile büyükleriyle ilgili kültürel normları ve tutumları etkileme potansiyeline sahip (Beland-Milly, 2001) belirli bir toplumdaki bir yetişkin ile aynı topluma ait olan yetişkinlerin bilgi ve deneyimlerinden ve duygusal olgunluktan yoksun bir çocuk arasında bağ kuran bir bildiri, bir tarihsel iletişim” (Soriano, 1979: 21) olarak görülmektedir. Günümüz yazarlarınca kaleme alınan çocuk kitaplarında yer alan nine ve dede karakterlerinin çocuğun gelişim ihtiyaçlarına cevap verebilecek biçimde oluşturulup oluşturulmadığı, nesiller arası aktarımın ne kadar ve ne şekilde gerçekleştiği incelenmesi gereken bir husustur. Bu bağlamda çocuk kitaplarında yer alan nine ve dede karakterlerinin sunuluş biçimlerinin incelenmesine katkı sağlayabilecek bazı başat başlıklara değinmek gerekmektedir. Alanyazın araştırması ve 9 uzman görüşü alınarak oluşturulan bu başlıklar; sözlü edebiyat aktarımı, okuma kültürü, gelenek aktarım1, dinî eğitim, ahlak eğitimi, oyun, günlük yaşam, dil bilinci, tecrübe, tarih şuuru, edebiyat- sanat-müzikle ilgili aktarımlar, aile geleneğinin aktarımı, söz 
varlığı, kuşaklar arası farklılıklar, vatan sevgisi, bilgi aktarımı, hayal gücü eğitimi, problem çözme ve olumsuzluklardır.

Yazının bulunmadığı dönemlerde oluşan, ağızdan ağıza, kuşaktan kuşağa geçerek varlı̆̆ını sürdüren (Özdemir, 1980: 44) sözlü edebiyat; bir milletin görüş, duyuş, düşünüş, yaşam biçimi ve tarihsel yürüyüşünün aynasıdır. Nine ve dede karakterleri, torunlarına masal anlatarak, onlara ninni, mâni, tekerleme vb. söyleyerek hem sözlü kültürü kazandırma/ aktarma görevini yerine getirebilir hem de çocukların dil, kişilik, hayal gücü, bilişsel ve toplumsal becerilerinin gelişmesinde büyük rol oynayabilir.

Çocukların okuma becerilerinin geliştirilmesinde onlara erken çocukluk dönemlerinden itibaren okunan kitapların çok büyük etkisi vardır. "Çocuk, hem sevdiği bir kimseyle birliktelikten dolayı mutlu olur hem de kitabın kendisine sunduğu dilsel ve görsel olanaklarla yeni yaşantılar edinmeye başlar" (Sever, 2008: 21). Torunlarına okuma sevgisi kazandıracak nine ve dede karakterlerinin çocuk kitaplarına yansıtılması çocukların okuma kültürünü kazanmalarına ve münevver şahsiyetler hâline gelmelerine katkı sağlayabilir.

Ortak tarih, ulusların hafızasıdır, insan topluluklarını millet yapmak için gerekli en temel niteliklerden biridir. Bu şuur, bireylerde aidiyet hissinin vuku bulmasına hizmet eder. "Her toplum, gelen nesillerin ayaklarını ülke ve milletine dair kuvvetli bir tarihî zemine bastırarak kişiye öncelikle bir grubun parçası olduğunu hissettirir. Bu his bireyin dünya üzerinde zaman ve mekân bağlamında varlığını temellendirebilmesini sağlar" (Ceyhan, 2009: 338). Ulusal tarih hakkında daha fazla bilgi sahibi olan (Smith, 2005) nine ve dede karakterleri torunlarına anılar, destanlar, fetih ve yiğitlik hikâyeleri vb. anlatarak çocukların tarih şuuruna sahip olmalarına yardımcı olabilir.

Günlük yaşamla ilgili aktarımlar, okul öncesi dönemden başlayarak çocuğun çeşitli gelişim evrelerinde sorumluluk alma, bağımsız iş yapabilme ve sosyalleşme gibi pek çok konuda yeterlilik kazanmasını sağlar. Yaşam becerileriyle donanmış çocuklar hayatın zorluklarıyla daha kolay baş edebilirken yaşam memnuniyet düzeyleri de akranlarına nazaran daha yüksek olabilmektedir (Norman -Jordan, 2015). Büyük ebeveyn karakterleri vasitasıyla çocuklara sofra adabı, misafir ağırlama, selamlaşma/vedalaşma, iletişim gibi günlük yaşamda ihtiyaç duyabilecekleri çeşitli hususlar aktarılabilir. 
"Vatan aralarında millî bağlar bulunan insan topluluklarının üzerinde birlikte yaşadıkları, gerektiğinde uğrunda canın ve malın feda edildiği” maddi varlığının ötesinde atalarımızdan bize, bizden de gelecek nesillere devredilecek manevi bir mirastır (Çiftçi- Dikmenli, 2016: 847). Türk toplumunda vatan sevgisi kutsal kabul edilmektedir. Bu sevginin kuşaktan kuşağa aktarılması milletin varlığını sürdürebilmesi için elzemdir. Çocuk kitaplarında yer alan nine ve dedelerin torunlarına tarihten anılar, kahramanlık hikâyeleri vb. anlatmaları çocukların kalbine vatan sevgisinin nakşedilmesine katkı sağlayabilir.

Türk kültüründe bayramda büyüklerin ellerinin öpülmesi, yeme-içme, düğün, batıl inanç, asker uğurlama, doğum, evlenme gibi pek çok gelenek ve görenek bulunmaktadır. Aile büyükleri eski deyişle "ulular" yüzyıllardır en büyük gelenek aktarıcısı sıfatıyla geçmişle gelecek arasında köprü vazifesi görmüştür. Torunlarına aile ve toplum geleneklerini aktarabilen (Hillman, 1999; Kornhaber, 1996) nine ve dedelere çocuk kitaplarında yer verilerek geleneksel ve kültürel ögeler yeni nesillere tanıtılabilir.

"Din duygusu çocukta doğuştan var olan, insan fitratına bağlı derin bir heyecandır" (Ay, 2015: 75). İnanma ihtiyacı hisseden, dinî duyguları uyanan çocuklar ilk dinî bilgilerini büyüklerini taklit ederek edinir. Çocukların ihtiyaç duydukları dinî eğitimi (dinî terimleri, uyku duaları, iman ve ibadet esasları, peygamber kıssaları vb.) alabilmelerinde dede ve nine karakterlerinin sevgi ve şefkat temelli metotlarından faydalanılabilir.

"Sanat, çocukların eğitiminde hayati rol oynayan önemli bir etkendir" (Yavuzer, 2018: 160). "Çocukların yoğun olan yaratıcılık ve estetik duygularının erken yıllarda desteklenmemesi ileriki yıllarda yaratıcı, üretken ve çevrelerindeki güzellikleri algılayan bireyler olmalarını da engelleyebilmektedir" (Feeney-Moravcik, 1987). Bu bağlamda çocuk kitaplarında yer alan nine ve dedeler torunlarıla sinemaya, tiyatroya giderek onlarla birlikte resim yaparak meddah, Karagöz Hacivat gibi geleneksel seyirlik oyunlardan yararlanarak anlattıkları hikâyelerle söyledikleri türküler, ninnilerle çocuğun duygusal ve estetik gelişimini destekleyebilir.

Çocuklar hayata yeni adım attıkları, yolun henüz başında oldukları için kendilerine rehberlik edecek büyüklere ihtiyaç duyarlar. Bu süreçte büyük ebe- 
veynler sahip oldukları bilgileri torunlarıyla paylaşırlar. Bilgi aktarımı sırasında büyük ebeveynler torunlarına bir şey öğretmenin mutluluğunu yaşarken unuttukları bilgileri yeniden hatırlarlar ve çift yönlü öğrenme süreci sayesinde yeni nesillerden de bir şeyler öğrenerek yaşam boyu öğrenmeyi gerçekleştirirler. Çocuk kitaplarında yer alan nine ve dede karakterleri vasıtasıyla nesiler arası paylaşım ve dayanışmanın gerçekleşmesi kolaylaştırılabilir.

Yaşanılan problemlerde "büyüklere danışma” Türk kültüründe sıkça başvurulan bir yöntemdir. Büyük ebeveynler, karşılaşılan zorluklarda bilgi ve tecrübelerinden faydalanarak sorunlara çözüm yolu bulabilirler. İyi kurgulanmış nine ve dede karakterleri, çocukların problem çözme becerilerinin gelişmesine yardımcı olurken onlara zorluklarla başa çıkmak için mücadele kuvveti de sunabilir.

Çocuğun en güçlü ve doğal dürtülerinden biri olan oyun (Yavuzer, 2018: 170), onların fiziksel, duygusal, bilişsel ve dilsel gelişimine katkı sağladığı gibi sosyalleşmesine de yardımcı olur. Önceki kuşakların sokakta grupça oynadıkları oyunlar yerine yeni nesil, iç mekânlarda bireysel oyunlara yönelmiştir. Nine ve dede karakterleri; doğayı keşfetme, hayal gücü ve el becerisinin geliştirilmesi gibi pek çok faydası olan geleneksel oyunların öğrenilebileceği etkili kaynaklar olmanın yanı sıra yeni nesilleri modern oyunların barındırabileceği bazı tehlikelere karşı da koruyabilir.

Yurt dışında yapılan büyük ebeveyn-torun araştırmaları, büyük ebeveyn torun ilişkisi (Dunifon-Bajracharya, 2012) ile büyükanne ve büyükbabaların çocuk kitaplarındaki tasvirlerine (Janelli, 1988; Fenwick-Morrison, 2001) odaklanmıştır. Türkiye'de aile büyükleri ile ilgili çalışmalar büyük oranda büyük ebeveyn ve torunların birbirleriyle ilgili görüşleri (Arpacı-Bekâr, 2013; Demiriz-Arpac1, 2016) üzerine yoğunlaşmıştır. Az sayıda büyük ebeveyn-torun ilişkisini (Alperen, 2013; Kılıç, 2018) ele alan çalışmalar da mevcuttur.

Büyük ebeveyn-torun ilişkisini ve aktarımını konu edinen araştırma ve çocuk kitabı sayısı sınırlıdır. Alanyazında aile üyeleri ile ilgili karakter incelemelerinin yer aldığı bazı çalışmalara rastlansa da aile büyüklerinin sunuluş biçimlerinin doğrudan incelendiği bir araştırma tespit edilmemiştir. Büyük ebeveyn-torun araştırmalarına daha çok sosyoloji, psikoloji ve sosyal hizmetler alanlarında yapılan çalışmalarda rastlanmaktadır. 
$\mathrm{Bu}$ araştırma, çağdaş çocuk kitaplarında aile büyüklerinin sunuluş biçimlerinin ele alındığ ilk çalışmalardan biridir. Aynı zamanda çocuk edebiyatı, sosyoloji, eğitbilim gibi alanlarda aile büyükleri, nine/ dedeler veya yaşl1larla ilgili yapılmış çalışmaların sınırlı olması da bu araştırmayı önemli kılmaktadır.

$\mathrm{Bu}$ çalışmanın amacı, çağdaş çocuk kitaplarında yer alan aile büyüklerinin sunuluş biçimlerinin incelenmesidir. Araştırmada elde edilen bulguların yozlaşma, köksüzleşme tehlikesine karşı sağlıklı kurulan büyük ebeveyn-torun ilişkisi ve aktarımının ele alındığı nitelikli çocuk edebiyatı ürünlerinin sayısının arttırılmasına katk1 sağlayacağı düşünülmektedir.

"Çağdaş çocuk kitaplarında nine ve dede karakterlerinin nasıl sunulduğu" sorusuna cevap aranılan bu araştırmada büyük ebeveyn- torun arasındaki etkileşim ile kuşaklar arası maddi ve manevi değerlerin vb. aktarımı üzerinde odaklanılmıştır. İncelenen eserlerde tespit edilen hususlara dair bilgilere bulgular bölümünde değinilmiştir.

\section{Yöntem}

Bu bölümde araştırmanın deseni, araştırma inceleme nesneleri, verilerin toplanması ve analizine yer verilmiştir.

\section{Araştırmanın Deseni}

Nitel araştırma yöntemlerinden iç içe geçmiş tek durum deseni ile yapılandırılan çalışmada doküman analizi tekniğinden faydalanılmıştır. Durum çalışmas1, bilginin toplanıp organize edilmesi, yorumlaması ve araştırma bulgularına ulaşılması gibi basamakları ihtiva eden sistematik desen türlerinden biri (Merriam, 1988) olup "bir durum hakkında detaylı betimlemeler yapmak ve o durumu var olduğu şekliyle anlamak için kullanılır” (Büyüköztürk vd. 2016: 264). Doküman analizi ise "araştırılması hedeflenen olgu ve olaylar hakkında bilgi içeren yazılı materyallerin analizini kapsar" (Yıldırım ve Şimşek, 2016: 217). Araştırmada çağdaş çocuk kitaplarında yer alan nine ve dede karakterlerinin sunuluş biçimleri durum olarak kabul edilmiş ve büyük ebeveyn-torun ilişkisinin ve aktarımının boyutları analiz edilmiştir. 


\section{Araştırmanın İnceleme Nesneleri}

$\mathrm{Bu}$ araştırmanın inceleme nesnelerini belirlemek için amaçlı örnekleme tekniklerinden biri olan "belli ölçütleri sağlayan durumların seçildiği”" (Patton, 2014: 243) “ölçüt örneklem stratejisi”nden yararlanılmıştır. Büyüköztürk-Kılıç Çakmak vd.'e göre (2016) ölçüt örneklem; örneklemin problemle ilgili olarak belirlenen niteliklere sahip kişiler, olaylar, nesneler ya da durumlardan oluşturulmasıdır (Büyüköztürk-Kılıç Çakmak vd., 2016: 92).

İnceleme nesneleri belirlenirken takip edilen yol şu şekildedir:

- Kütüphanelerin veri tabanları, yayınevlerinin internet siteleri ve katalogları incelenmiştir.

- Türkiye'de yerli yazarlar tarafından kaleme alınan; kapak resminde, anahtar kelimelerinde, içeriğinde büyük ebeveyn-torun ilişkisi ve aktarımına yer verilmiş olan 90 çocuk kitabı belirlenmiştir.

- Alan uzmanlarının görüşleri doğrultusunda günümüz yazarları tarafından kaleme alınmamış, çağdaş çocuk kitabı kategorisinde yer almayan 45 kitap elenmiştir.

- Kitaplarda yer alan, büyük ebeveyn-torun iletişim ve aktarımına dair belirleyici katkısı olmadığı tespit edilen nine ve dede karakterlerini barındıran 30 kitap tasnif dışı bırakılarak örnekleme dâhil edilmemiştir.

- Alan uzmanlarının görüşlerinden yararlanılarak araştırma konusu ile ilgili birden fazla eseri olan yazarların yalnızca bir kitabı incelemeye dâhil edilmiştir. Büyük ebeveyn-torun ilişkisinin ve aktarımının temel alındığı, nine ve dede karakterlerinin belirleyici rolü bulunan, çağdaş çocuk kitapları kategorisinde yer alan ve Türk yazarlarca kaleme alınmış olan on beş çocuk kitabı araştırmanın inceleme nesneleri olarak belirlenmiştir. 
Tablo:1. Araştırmada Kullanılan Çocuk Kitapları ve Yayınevleri

\begin{tabular}{|c|l|l|l|}
\hline No & \multicolumn{1}{|c|}{ Kitap Adı } & \multicolumn{1}{|c|}{ Yazarı } & \multicolumn{1}{|c|}{ Yayınevi } \\
\hline 1 & Yeşilcik & Cemil Kavukçu & Can Çocuk \\
\hline 2 & Gemici Dedem & Sevim Ak & Can Çocuk \\
\hline 3 & Dedemi Kimseye Kaptırmam & Üzeyir Gürbüz & Küçük Ev Yayınları \\
\hline 4 & $\begin{array}{l}\text { Dedem Benim En İi } \\
\text { Arkadaşım }\end{array}$ & Aydoğan Yavaşlı & Nova Kids \\
\hline 5 & Yasemin ve Lavanta & Sevgi Saygı & Günışı̆̆ı Kitaplığı \\
\hline 6 & Çetin Çeviz & Sinan Yaşar & Fom Kitap \\
\hline 7 & Dedemin Ayçiçeği Tarlası & Gamze Pat & Altın Kitaplar \\
\hline 8 & Dedemin Uçan Dairesi & Koray Avcı Çakman & Tudem \\
\hline 9 & Taşkafa & Ömer Açık & Günışı̆̆ı Kitaplığı \\
\hline 10 & Dedemin Bakkalı & Şermin Yaşar & Taze Kitap \\
\hline 11 & Dedem Eve Dönüyor & $\begin{array}{l}\text { Nehir Aydın } \\
\text { Gökduman }\end{array}$ & $\begin{array}{l}\text { Diyanet İşleri } \\
\text { Başkanlı̆̆ Yayınları }\end{array}$ \\
\hline 12 & Dünyanın En Talihli Vapuru & Gamze Sürcan & $\begin{array}{l}\text { Türkiye Iş Bankası } \\
\text { Yayınları }\end{array}$ \\
\hline 13 & $\begin{array}{l}\text { Ninemin Yemekleri Dedemin } \\
\text { Oyuncakları }\end{array}$ & Mehmet Güler & Nesin Yayınevi \\
\hline 14 & Anneannem Gelin Oldu & Muzaffer İzgü & Bilgi Yayınevi \\
\hline 15 & Anneannemin Güzel Çiçekleri & Alp Gökalp & Can Çocuk \\
\hline & & & \\
\hline
\end{tabular}

\section{Verilerin Toplanması}

Araştırmada verilerin toplanmasında izlenen yol şu şekildedir:

- Öncelikle büyük ebeveyn-torun ilişkisi ve aktarımıyla ilgili alanyazın taraması yapılmıştır.

- Ardından büyük ebeveynlerin sunuluş biçimlerinin belirlenmesi amacıyla çocuk kitapları araştırmacı tarafindan okunmuş ve incelenmiştir. Elde edilen veriler üzerinde içerik analizi uygulanmış ve nine/dede karakterlerinin torunlarıyla kurduğu ilişki ve aktarım biçimleri kodlanmıştır.

- Kodlama sonucu ilk etapta 42 alt birimi kapsayan 19 temel kategori oluşturulmuştur.

- Oluşturulan kategoriler 8 alan uzmanının görüşüne sunulmuştur. Alan 
uzmanlarının görüşleri doğrultusunda “dil bilinci” temel kategorisine iki alt birim (doğrudan/ dolaylı) eklenerek kategoriler nihai hâlini almıştır. Buna göre, 44 alt birimi kapsayan 19 temel kategoriden meydana gelen büyük-ebeveynlerin sunuluş biçimlerinin incelendiği bir kategori formu oluşturulmuş ve mevcut form veri toplama aracı olarak kullanılmıştır.

\section{Verilerin Analizi}

Verilerin analizi iki safhada gerçekleşmiştir:

Birinci safhada 15 çağdaş çocuk kitabında yer alan nine ve dede karakterlerinin sunuluş biçimlerinin tespit edilmesi amacıyla "içerik analizi tekniği” kullanılmıştır. İçerik analizinde amaç, toplanan verileri açıklamaya yardımcı olacak ilişkilere veya temalara ulaşmaktadır. Bunu gerçekleştirebilmek için tümevarımcı analizden yararlanılır. Tümevarımcı analizde önce içerik kodlanmakta daha sonra bu kodlardan kavramlara ve nihayet elde edilen kavramlardan temalara ulaşılmaktadır (Yıldırım-Şimşek, 2016: 242).

Araştırmada içerik analizinden elde edilen veriler kodlanmış ve bu kodlardan yararlanılarak temel analiz birimi olan kavramlara ulaşılmıştır. Daha sonra bu kavramlar, belirli bir tema altında sınıflandırılarak bir kategori formu oluşturulmuş ve veriler mevcut forma işlenmiştir.

İkinci safhada içerik analizi ile kategori haline getirilerek forma işlenen veriler, betimsel analiz ile yorumlanmıştır. Betimsel analizde, "elde edilen verilerin daha önceden belirlenmiş temalara göre özetlenmesi ve yorumlanması" esastır (Y1ldırım-Şimşek, 2016: 239).

\section{Bulgular}

Bu bölümde araştırma sorusu kapsamında ulaşılan bulgulara yer verilmiştir. 
Tablo:2. Çağdaş Çocuk Kitaplarında Unsur Çeşittiliği

\begin{tabular}{|l|c|c|}
\hline \multicolumn{1}{|c|}{ Kitaplar } & Unsur Çeşitliliği & \% \\
\hline K1-Y & 17 & $6,67 \%$ \\
\hline K2-GD & 17 & $6,67 \%$ \\
\hline K3-DKK & 18 & $7,06 \%$ \\
\hline K4-DBEİA & 17 & $6,67 \%$ \\
\hline K5-YVL & 15 & $5,88 \%$ \\
\hline K6-ÇÇ & 9 & $3,53 \%$ \\
\hline K7-DAT & 17 & $6,67 \%$ \\
\hline K8-DUD & 23 & $9,02 \%$ \\
\hline K9-T & 16 & $6,27 \%$ \\
\hline K10-DB & 14 & $5,49 \%$ \\
\hline K11-DED & 20 & $7,84 \%$ \\
\hline K12-DETV & 14 & $5,49 \%$ \\
\hline K13-NYDO & 22 & $8,63 \%$ \\
\hline K14-AGO & 20 & $7,84 \%$ \\
\hline K15-AGÇ & 16 & $6,27 \%$ \\
\hline
\end{tabular}

*İncelemeye olumsuzluklar dâhil edilmemiştir.

Kitaplarda belirlenen nine ve dedelerin sunuluş biçimlerinin unsur içerme çeşitliliği şöyledir:"Dedemin Uçan Dairesi" (23), "Ninemin Yemekleri Dedemin Oyuncakları" (22), “Anneannem Gelin Oldu” (20), "Dedem Eve Dönüyor” (20), "Dedemi Kimseye Kaptırmam" (18), "Yeşilcik" (17), "Gemici Dedem" (17), "Dedem Benim En İyi Arkadaşım" (17), "Dedemin Ayçiçeği Tarlası" (17), "Taşkafa" (16), "Anneannemin Güzel Çiçekleri” (16), "Yasemin ve Lavanta" (15), "Dedemin Bakkalı" (14), "Dünyanın En Talihli Vapuru” (14), “Çetin Ceviz" (9).

İncelenen çocuk kitapları arasında en fazla unsur çeşitliğine sahip olan "Dedemin Uçan Dairesi" (23) isimli kitaptır. Ardından sırasıyla "Ninemin Yemekleri Dedemin Oyuncakları" (22), "Dedem Eve Dönüyor" (20) ve "Anneannem Gelin Oldu" (20) isimli çocuk kitapları gelmektedir. En az unsur çeşitliliğine sahip olan "Çetin Ceviz" (9) isimli kitaptır. 
Tablo:3. Çăgdaş Çocuk Kitaplarında Yer Alan Toplam Unsurlar

\begin{tabular}{|l|c|c|}
\hline \multicolumn{1}{|c|}{ Kitaplar } & Unsur Çeşitliliği & \% \\
\hline K1-Y & 64 & $10,22 \%$ \\
\hline K2-GD & 38 & $6,07 \%$ \\
\hline K3-DKK & 47 & $7,51 \%$ \\
\hline K4-DBEİA & 36 & $5,75 \%$ \\
\hline K5-YVL & 35 & $5,59 \%$ \\
\hline K6-ÇÇ & 22 & $3,51 \%$ \\
\hline K7-DAT & 28 & $4,47 \%$ \\
\hline K8-DUD & 53 & $8,47 \%$ \\
\hline K9-T & 32 & $5,11 \%$ \\
\hline K10-DB & 37 & $5,91 \%$ \\
\hline K11-DED & 49 & $7,83 \%$ \\
\hline K12-DETV & 29 & $4,63 \%$ \\
\hline K13-NYDO & 74 & $11,82 \%$ \\
\hline K14-AGO & 54 & $8,63 \%$ \\
\hline
\end{tabular}

Kitaplarda belirlenen nine ve dedelerin sunuluş biçimlerinin toplam unsur oranı şöyledir:

"Ninemin Yemekleri Dedemin Oyuncakları” (81), “Anneannem Gelin Oldu" (58), "Yeşilcik" (57), “Gemici Dedem" (55), "Dedemin Uçan Dairesi” (54), “Dedemi Kimseye Kaptırmam” (49), “Dedem Eve Dönüyor” (44), “Anneannemin Güzel Çiçekleri”" (38), "Dedemin Bakkalı" (36), "Yasemin ve Lavanta" (35), "Dedem Benim En İyi Arkadaşım” (34), "Taşkafa” (34), "Dedemin Ayçiçeği Tarlası” (30), “Dünyanın En Talihli Vapuru” (29), "Çetin Ceviz” (23).

İncelenen eserler arasında "toplam unsur oranı" en fazla olan "Ninemin Yemekleri Dedemin Oyuncakları" (81) isimli kitaptır. Ardından sırasıyla "Anneannem Gelin oldu" (58), "Yeşilcik" (57) ve "Gemici Dedem" (55) isimli çocuk kitapları gelmektedir. En az unsur içeren "Çetin Ceviz" (23) isimli kitaptır. 
Tablo:4. Ana Kategori Oranlarl

\begin{tabular}{|c|c|c|}
\hline Kitaplar & Unsur Çeşitliliği & $\%$ \\
\hline 1.Sözlü Edebiyatın Aktarımı & 10 & $3,73 \%$ \\
\hline 2.Okuma Kültürü & 9 & $3,36 \%$ \\
\hline 3.Gelenek Aktarımı & 42 & $15,67 \%$ \\
\hline 4.Dini Eğitim & 8 & $2,99 \%$ \\
\hline 5.Ahlak Eğitimi & 5 & $1,87 \%$ \\
\hline 6.Oyun & 10 & $3,73 \%$ \\
\hline 7.Günlük Yaşam & 67 & $25,00 \%$ \\
\hline 8.Dil Bilinci & 11 & $4,10 \%$ \\
\hline 9.Tecrübe & 12 & $4,48 \%$ \\
\hline 10.Tarih Bilinci & 2 & $0,75 \%$ \\
\hline $\begin{array}{l}\text { 11.Edebiyat-Sanat- Müzikle İlgili } \\
\text { Aktarımlar }\end{array}$ & 8 & $2,99 \%$ \\
\hline 12.Aile Geleneğinin Aktarımı & 10 & $3,73 \%$ \\
\hline 13.Söz Varlığının Geliştirilmesi & 13 & $4,85 \%$ \\
\hline 14.Kuşaklar Arası Farklılıklar & 22 & $8,21 \%$ \\
\hline 15. Vatan Sevgisi & 0 & $0,00 \%$ \\
\hline 16.Bilgi Aktarımı & 13 & $4,85 \%$ \\
\hline 17.Hayal Gücü Eğitimi & 9 & $3,36 \%$ \\
\hline 18.Problem Çözme & 12 & $4,48 \%$ \\
\hline 19.Olumsuzluklar & 5 & $1,87 \%$ \\
\hline
\end{tabular}

Nine ve dede karakterlerinin sunuluş biçimleri ana kategorileri içerme oranı en fazla olan "günlük yaşam" (\%25) kategorisidir. Ardından "gelenek aktar1mı" (\%15,67) kategorisi gelmektedir. Eserlerde "vatan kategorisi" (\%0) ile ilgili aktarıma hiç yer verilmediği tespit edilmiştir. Ardından en az unsurun tarih şuuru $(0,75 \%)$, ahlak eğitimi $(1,87 \%)$ ve olumsuzluklar $(1,87 \%)$ kategorilerinde bulunduğu saptanmıştır.

Çağdaş çocuk kitaplarında yer alan nine ve dede karakterlerinin sunuluş biçimleri ana kategori ve alt birim unsurlarının inceleme sonuçları ise şöyledir:

Eserlerde "sözlü edebiyat aktarımı" ana kategorisinde varlığı tespit edilen alt birimler; masal (6), bilmece (1), atasözüdür (3). Kitaplarda yer verilmeyen alt birimler ise; ninni, mâni, tekerleme, halk hikâyesi ve fikradır. 
"Okuma kültürü" ana kategorisinde kitaplarda varllğı tespit edilen alt birimler; okuma-yazma becerisinin geliştirilmesine katkı (3), okuma-yazma sevgisidir (6). Kitaplarda yer verilmeyen unsurlar; okuma-yazma öğretimi ve torunlara kitap okumadir.

"Gelenek aktarımı" ana kategorisinde kitaplarda varlığı tespit edilen alt birimler; yeme-içme (12), el sanatları (3), bayram (2), batıl inanç (1), geleneksel sporlar (1), geleneksel sanatlar (1), askerlik (1), meslekler (5), eşya (13), ad koymadır (2). Kitaplarda yer verilmeyen alt birimler düguün ve doğumdur.

"Dinî Eğitim" ana kategorisinde kitaplarda varllğı tespit edilen alt birimler; dinî terimler (4), dua (2), ve namazdır (2). Kitaplarda yer almayan alt birimler ise; din kuralları ve ilahidir.

"Oyun" ana kategorisinde kitaplarda yer alan alt birimler; oyunlar (2) ve oyuncaklardır (7).

"Günlük yaşam" ana kategorisinde kitaplarda varlı̆ğ tespit edilen alt birimler; yiyecek-içecekler (14), sofra adabı (1), misafir ağırlama (4), yaşanılan mekânlar (14), yeme-içme alışkanlıkları (4), kişiler arası iletişim: olumlu [15], olumsuz [7], selamlaşma/vedalaşmadır (8).

Eserlerde "dil bilinci" ana kategorisinden dolaylı katkıya (11) yer verildiği belirlenmiştir. Doğrudan katkı alt birimine yer verilmemiştir. "Kuşaklar arası farklılıklar" ana kategorisinde belirlenen alt birimler dış görünüş ve tavır-tutum/ yaşam biçimidir (19).

Eserlerde "ahlak eğitimi" (4), "tecrübe" (12), "tarih şuuru" (2), "edebiyat-sanat- müzikle ilgili aktarımlar" (8), "aile geleneğinin aktarımı” (10), "söz varlığının geliştirilmesi” (13), "bilgi aktarımı” (12), "hayal gücü eğitimi” (9), "problem çözme" (12) ve" olumsuzluklar" (5) ana kategorilerine ait unsurların var olduğu belirlenmiştir. Kitapların hiçbirinde "vatan sevgisi" ana kategorisine ait veri tespit edilmemiştir. 


\begin{tabular}{|c|c|c|c|c|c|c|c|c|c|c|}
\hline : & 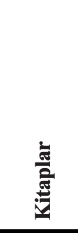 & 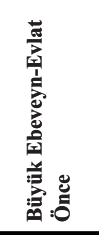 & 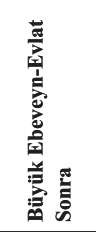 & 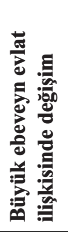 & 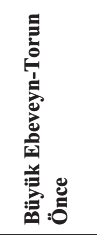 & 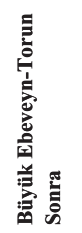 & 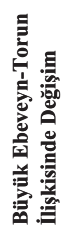 & 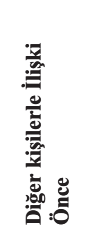 & 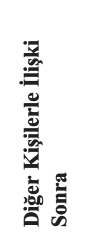 & 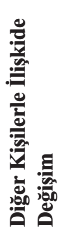 \\
\hline K.1 & Y & Olumlu & Olumlu & Yok & Olumlu & Olumlu & Yok & Yok & Yok & Yok \\
\hline K. 2 & GD & Olumsuz & Olumlu & Var & Olumlu & Olumlu & Yok & Yok & Yok & Yok \\
\hline K. 3 & DKK & Olumlu & Olumlu & Yok & Olumlu & Olumlu & Yok & Olumsuz & Olumlu & Var \\
\hline K.4 & DBEİA & Olumlu & Olumlu & Yok & Olumlu & Olumlu & Yok & Yok & Yok & Yok \\
\hline K. .5 & YVL & Olumlu & Olumlu & Yok & Olumlu & Olumlu & Yok & Yok & Yok & Yok \\
\hline K.6 & ÇÇ & Olumsuz & Olumlu & Var & Olumlu & Olumlu & Yok & Yok & Yok & Yok \\
\hline K.7 & DAT & Olumlu & Olumlu & Yok & Olumlu & Olumlu & Yok & Olumsuz & Olumlu & Var \\
\hline K. 8 & DUD & Olumlu & Olumlu & Yok & Olumlu & Olumlu & Yok & Olumsuz & Olumlu & Yok \\
\hline K.9 & $\mathrm{T}$ & Olumsuz & Olumlu & Var & Olumlu & Olumlu & Yok & Yok & Yok & Yok \\
\hline K.10 & DB & Olumlu & Olumlu & Yok & Olumsuz & Olumlu & Var & Yok & Yok & Yok \\
\hline K.11 & DED & Olumsuz & Olumlu & Var & Olumlu & Olumlu & Yok & Yok & Yok & Yok \\
\hline K.12 & DETV & Olumlu & Olumlu & Yok & Olumlu & Olumlu & Yok & Olumlu & Olumlu & Yok \\
\hline K.13 & NYDO & Olumlu & Olumlu & Yok & Olumlu & Olumlu & Yok & Yok & Yok & Yok \\
\hline K.14 & AGO & Olumlu & Olumlu & Yok & Olumlu & Olumlu & Yok & Yok & Yok & Yok \\
\hline K.15 & AGÇ & Olumlu & Olumsuz & Yok & Olumlu & Olumlu & Yok & Yok & Yok & Yok \\
\hline
\end{tabular}

Tablo.5'e göre eserlerde kişiler arası olumlu iletişim yoğunluktadır. Büyük ebeveyn-torun ilişkisinin büyük ebeveyn-evlat ilişkisine nazaran daha olumlu olduğu belirlenmiştir. Büyük ebeveyn-torun ilişkisinin olumsuz olduğu tek eser "Dedemin Bakkalı" isimli çocuk kitabıdır. Orada da torunun büyümesiyle birlikte olumsuz ilişki olumluya dönüşmüştür. Torunların arabulucu rolü sayesinde "Taşkafa", "Gemici Dedem", "Çetin Ceviz" gibi eserlerde başta olumsuz olan büyük ebeveyn-evlat ilişkileri daha sonra olumluya dönüşmüştür.

\section{Sonuç ve Tartışma}

$\mathrm{Bu}$ araştırma kapsamında çağdaş çocuk kitaplarında yer alan nine ve dede karakterlerinin sunuluş biçimlerinin ana kategorileri olarak belirlenen sözlü ede- 
biyat aktarımı, okuma kültürü, gelenek aktarımı, dinî eğitim, ahlak eğitimi, oyun, günlük yaşam, dil bilinci, tecrübe, tarih şuuru, edebiyat-sanat-müzikle ilgili aktarımlar, aile geleneğinin aktarımı, söz varlığının geliştirilmesi, kuşaklar arası farkl1lıklar, vatan sevgisi, bilgi aktarımı, hayal gücü eğitimi, problem çözme, olumsuzluklar alt problemlerine ait şu sonuçlara ulaşılmıştır:

İncelenen eserler içinde nine ve dede karakterlerinin sunuluş biçimlerinden en fazla "günlük yaşam becerileri” ana kategorisine yer verildiği tespit edilmiştir. Bu ana kategori içinde en büyük oran "kişiler arası iletişim” alt biriminden "olumlu iletişim'e" (5,70\%) aittir. Bu yönüyle bulguların Fenwick ve Morrison'un (2008) "büyük ebeveynlerin torunlarıyla genelde olumlu ilişki kurduğu”, Arpacı ve Bekar'ın (2013) "küçük yaş grubundaki çocukların büyük ebeveynlere bakış açısının daha olumlu” olduğu ve Hazer'in (2012: 127) "ergenler içinde nine ve dedesini misafirperver, iyi kalpli, hoşgörülü ve cömert algılayanların ortalama değerlerinin en yüksek olması” araştırma sonuçlarıyla örtüştüğü görülmektedir.

"Günlük yaşam” ana kategorisinde en çok yer verilen alt birimlerden biri “yiyecek ve içecekler”, diğeri "yaşanılan mekânlar"dır. Eserlerde genellikle Türk mutfağında bulunan (tahin, pekmez, bal, süt, köfte vb.) ve toprağımızda sıkça yetişen (domates, patlıcan, erik, kiraz vb.) yiyecek-içeceklere yer verildiği tespit edilmiştir. Araştırma verileri Türkmen'in (2012: 149) Pepee'nin Anadolu coğrafyasında yetişen sebze/meyvelerle ve mutfağımızda sıkça pişen yemeklerle beslendiği bulgusunu desteklemektedir. Ayrıca yiyecek-içecek hazırlama eylemini ninelerin üstlendiği eserlerin (Y, NYDO) yanı sıra dedelerin de mutfağa girip yemek yaptığı eserler de mevcuttur (GD, T, DKK). Bu bulgunun cinsiyet eşitliği vurgusunu ve yardımlaşma olgusunu güçlendirerek çocuk gelişimine katkı sağlayabileceğini söylemek mümkündür. Yaşanılan mekânlar alt birimiyle ilgili olarak nine ve dedelerin büyük oranda köyde doğa ile iç içe bir hayat yaşadıkları tespit edilmiştir. Araştırma bulgularıyla benzer biçimde Rousseau (2016), "Emile”de çocuğun evde dört duvar arasında yetişmesini değil, doğal ortamda, tabiatla iç içe gelişimini sürdürmesini savunmaktadır. Koşkunlu (2008) çalışmasında Hikmet Hanım karakterinin geleneksel eşyaları, bayram, sünnet, düğün gibi törenleri ve geleneksel yemekleri torunlarına öğrettiğini saptamıştır. Kutadgu Bilig'de de (Hacip, 2003: 331) düğün, doğum, sünnet ziyafeti gibi geleneklere yer verilmektedir. 
Eşitti'nin (2016) yaptı̆̆ı çalışmada, anne-babası çalıştığı için ninesi ve dedesiyle kalan Pepee'nin Türk kültürüne ait pek çok geleneği büyük ebeveynlerinden öğrendiği bilgisi araştırma bulgularını destekler niteliktedir. Ancak incelenen eserler arasında "Ninemin Yemekleri ve Dedemin Oyuncakları" isimli çocuk kitabı dışında yöresel yemeklerde çeşitlenme tespit edilmemiştir. Geleneksel yeme-içme alt biriminde çoğunlukla "tarhana çorbası"na (DKK, YVL, AGO vb.) yoğunlaşıldığı saptanmış ve bunun da geleneksel yemeklerin aktarımında tek tipleşme eğilimine sebep olabileceği öngörülmüştür.

Araştırma nesnesi olan çağdaş çocuk kitaplarında nine ve dede karakterlerinin "Vatan Sevgisi" ana kategorisiyle ilgili aktarımına rastlanmamıştır. Yılmaz ve Duman'ın (2017: 652) çalışmasında da TRT Çocuk Dergilerindeki vatan-vatanseverlik değerinin $(\% 3,17)$ aktarımının yetersiz olduğu sonucuna ulaşılmıştı. Sallabaş’ın (2012: 64) çalışmasında Ömer Seyfettin'in hikâyelerinde vatanseverlikle ilgili 12 değer saptanmasına karşın çağdaş yayınlarda vatan sevgisine dair aktarıma hiç yer verilmemesi veya kısıtlı yer verilmesi bir eksiklik olarak değerlendirilmiştir.

İncelenen eserlerde en az yer verilen ikinci ana kategori ise "Tarih Şuuru"dur. Önkaş'ın (2016) Türkçe ders kitaplarında tarih bilinci oluşturacak nitelikli eserlerin bulunmadığı, Atatürkçülük teması dışında tarih bilinciyle ilgili metinlere yer verilmediği tespiti araştırma sonucunu destekler niteliktedir. Benzer şekilde Taşdemir ve Coşkun (2016) da Türkçe ders kitaplarında tarihî değerlerin en çok Atatürk temasında yer aldığını, bu zenginliğin diğer temalara da taşınmas1 gerektiğini belirtmiştir. Topçu'nun (2016: 118) "Tarih şuuru eksik bırakılarak yetiştirilen çocuk gerçek vatandaş olamayacaktır.” sözünden yola çıkarak çağdaş çocuk kitaplarında tarih şuurunu geliştirmeye yönelik aktarımların kısıtlı olmasının gelecek nesillerin yetiştirilmesinde sorun teşkil edebileceği öngörülmüştür.

"Sözlü edebiyat aktarımı" ana kategorisi içinde en fazla "masal" alt birimine yer verilmiştir. Araştırmanın bulguları Altan ve Tarhan (2018) ve Fırat (2018) ile örtüşmektedir. Altan ve Tarhan (2018), büyükannelerin torunlarına masal anlattı̆̆ını tespit etmiştir. Fırat (2018) ise büyük ebeveynlerin sözlü edebiyat ürünleri ve bilhassa masal vasıtasıyla kültür aktarımını gerçekleştirdiğini, yazılı hâlleri olmasına rağmen torunların nine ve dedelerinden masal dinlemekten zevk aldıklarını belirtmiştir. Benzer biçimde İlhan'ın (2017) Tanpınar'la ilgili yaptığı 
çalışmada da Tanpınar'ın edebî kişiliğinin oluşmasında sözlü kültürle yoğrulan, masalın hâkim olduğu büyükanneli evlerde büyümesinin etkili olduğuna değinilmiştir. Elde edilen bulgular doğrultusunda sözlü edebiyat aktarımı kategorisinde çoğunlukla masal üzerinde odaklanılışı, atasözü ve bilmeceye çok az, ninni, mâni ve tekerlemeye hiç yer verilmeyişinin çocuğun sözlü kültürü edinmesinde eksiklik oluşturabileceği sonucuna varılmıştır.

Eserlerde "Okuma Kültürü" ana kategorisinden en fazla "okuma-yazma sevgisi" alt birimine, ardından "okuma-yazma becerisinin geliştirilmesine katkı" unsuruna rastlanmıştır. Araştırma bulgularıyla benzer biçimde Maraşlı (2012: 29) da okuma sevgisi olmadan okuma alışkanlığının oluşmasının çok zor olduğunu ifade etmiştir. Demiriz ve Arpacı (2016) ise kitap inceleme etkinliğinde okul öncesi çocukların hem dedelerini hem de ninelerini tercih ettiğini saptamıştır. Öztürk (2003) de evlerde nine ve dedelerin gerçekleştirdiği okuma toplantılarının vazgeçilmez bir etkinlik olduğunu belirtmiştir.

İncelenen eserlerde "Dinî Eğitim" ana kategorisinde en çok dinî terimler ardından namaz ve dua alt birimlerine yer verilmiştir. Apaydın (2001) ilk çocukluk döneminde dinin taklitle öğrenildiğini ifade etmiş, çocuğun yakınlarının dinî yaşantısını örnek aldığını belirtmiştir. Aybey (2018) ise çocuğa dinî değerlerin aktarılmasında ailenin mühim bir rol üstlendiği bilgisine yer vermiştir. Güler (2010: 29) de Türk kültüründe yemekten sonra sofra duasının yapılmasının çok yaygın bir gelenek olduğunu aktarmıştır. Araştırma bulgularından ve yapılan çalışmalardan yola çıkılarak toplumun ve yaşamın bir parçası olan dinin çocuk kitaplarında yer almasının olağan olduğu çıkarımına varılmıştır.

İncelenen eserlerde "ahlak eğitimi" (4) ile ilgili paylaşımların yeterli düzeyde olmadığ 1 tespit edilmiştir. Sayıca az olan aktarımlarda kıskançlığın zararları, paylaşma, dürüstlük gibi konulara yer verilmiştir. Benzer biçimde Altan ve Tarhan da (2018) araştırmasında büyükannelerin torunlarına dürüstlük, merhamet gibi çeşitli değerleri aktardıklarını tespit etmiştir.

İncelenen eserlerde oyunlardan (2) ziyade oyuncaklara (7) yer verildiği belirlenmiştir. Oyun ve oyuncaklara dair en kapsamlı aktarımın "Yeşilcik" kitabında bulunduğu saptanmıştır. Eserde geleneksel oyun ve oyuncaklarla ilgili ayrıntılı bilgilere, yeni nesillerin oyun ve oyuncaklarındaki değişime yer verilmiştir. Araş- 
tırma bulguları, Tuğrul-Ertürk vd.'nin (2014) oyun malzemelerinin ve türlerinin kuşaktan kuşağa değiştiği tespitiyle örtüşmektedir. Eşitti (2016) çalışmasında dede karakterinin torununa geleneksel oyunları öğrettiğini tespit etmiştir. Artar, Onur ve Çelen (2002'den aktaran Tuğrul-Ertürk vd., 2014: 3) tarafından yapılan bir araştırmada ise "çocukların oynadığı oyunların sayısının, oyun türlerinin ve grup oyunlarının gittikçe azaldığı; oyun araçlarının doğal materyallerden yapılandırılmış fabrikasyon materyallere doğru değiştiği” belirtilmiştir.

İncelenen eserlerde "dil bilinci" ana kategorisinden yalnızca dolaylı katk1 alt birimine rastlanmıştır. Nine ve dede karakterlerinin, çocukta doğrudan dil bilinci oluşturacak bir ifadeye başvurmaktan ziyade eski kelimeleri kullanmak ve yabancı kelimelere başvurmamak suretiyle dolaylı katkıda bulunduğu tespit edilmiştir. Araştırma bulgularılya benzer biçimde Kıbrıs'ın (2016: 155) çalışmasında "Ayla Çınaroğlu'nun Selin karakteri aracılığıyla Türkçesi varken yabancı dilden sözcük alınmamasıyla ilgili olarak okuyucuyu bilinçlendirmeye çalışı̆̆ı̆” ifade edilmiştir. Türkmen'in (2013) çalışmasında da Pepee karakterinin İngilizce grandmother kelimesinin karşıllı̆ı olan büyükanne yerine "nene" diye seslenmesi dil bilincine örnek teşkil etmektedir.

Araştırma kapsamında incelenen eserlerden 12'sinde nine ve dede karakterlerinin tecrübelerini $(\% 4,56)$ torunlarıyla paylaştığ 1 tespit edilmiştir. Araştırma bulgularıla paralel olarak Doğan'ın (2005) çalışmasında Cahide Uçuk'un romanlarında bulunan dede ve nine karakterlerinin tecrübelerini torunlarına aktarışına yer verilmiştir. Uğur (2018) da yaptığı araştırmada torunlarının bakım sorumluluğunu üstlenen büyükannelerin onları yetiştirirken en çok müracaat ettikleri ve en güvenilir buldukları kaynağın kendi tecrübeleri olduğunu ifade ettiklerini belirlemiştir. Canatan (2008) çalışmasında yaşlıların tecrübelerini gençlere aktararak kültürel değerler ve bilginin devam etmesine katk1 sağladıklarına değinmiştir. Araştırma kapsamında incelenen 12 eserde tecrübe aktarımının yeterli olmadığ 1 saptanmıştır. Gürses ve Kılavuz da (2009: 98) torunların büyük ebeveynlerinin tecrübelerinden yeteri oranda yararlanma imkânı bulamadığını belirterek tecrübe aktarımının gerekliliğine vurgu yapmıştır.

İncelenen eserlerin 8'inde "edebiyat-sanat-müzik" ana kategorisinden türkü, şiir, resim ile ilgili aktarımlara yer verilmiştir. Arıcı (2016: 73), bireylerin 
dil ve edebiyat zevklerinin oluşması ve gelişmesinde çocuklukta büyüklerinden dinlediği ninni, masal, türkü, fikra, halk hikâyesi gibi halk edebiyatı ürünlerinin büyük katkı sağladığına değinmiştir. "Ninemin Yemekleri Dedemin Oyuncakları" ve "Dedemi Kimseye Kaptırmam" isimli çocuk kitaplarında türküye yer verilmesi, Kılıç ve Yılmaz’ın (2016) Beyaz Bulut Dergisi’yle ilgili çalışmasında yaşıı bireylerin çocuklara türkü ve ninni söylediği tespitiyle örtüşmektedir.

İncelenen eserlerin 10'unda aile geleneğinin aktarımı kategorisine $(\% 3,73)$ yer verildiği (Y, GD, DBEİA vb.) tespit edilmiştir. Çocuk kitaplarında aile geleneğinin aktarımı, ailenin korunmasına ve çocuk eğitimine olumlu katkı sağlayabilmektedir. Araştırma bulguları, Aluş’un (2015: 20) Türk ailesinin tarihi köklere sahip olduğu, ailevi değerlere önem verilen aile ortamında manevi gereksinimlerin doyurulabileceği tezini desteklemektedir.

İncelenen eserlerin 13'ünde büyük ebeveynlerin çocukların "söz varlığ1nı geliştirme"ye yönelik aktarımlarına yer verilmiştir. Bu aktarımların bir kısmı eski kelimeleri (Yeşilcik, Anneannem Gelin Oldu, Taşkafa vb.) canlı tutmaya, bir bölümü ise terim bilgisini (Gemici Dedem, Ninemin Yemekleri Dedemin Oyuncakları vb.) geliştirmeye yöneliktir. Göğüş (1978: 360), kelime bilgisinin derinlik, genişlik, ağırlık olarak üç boyutta tanımlandığını ifade etmiş ve Akyol (1997) da "kelime bilgisinin derinlik boyutunun ihmal edildiği" tespitinde bulunmuştur. Bu bağlamda büyük ebeveynlerin eski kelimeleri aktarması genişlik ve ağırlığın yanı sıra derinlik eğitimine de katkı sağlayacaktır. Onuk (2013: 28) ilkokul çağındaki çocukların söz varlığının gelişiminde masalların önemine vurgu yapmış, Arıcı (2016: 73) da ailede ninni, masal, tekerleme, deyim, atasözü, dua gibi zengin sözler kullanılarak çocukların söz varlığının geliştirilmesine katkı sağlanabileceğini ifade etmiştir.

İncelenen eserlerde kuşaklar arası dış görünüş (DKK, DBEİA, ÇÇ) veya tavır- tutum/yaşam biçimi (Y, YVL, DUD) farklılıklarından en az birine yer verildiği tespit edilmiştir. Kuşakların tutum ve değerlerinin farklılığg; çocukluk, gençlik, yaşlılık gibi yaşam evrelerinden (Appelbaum-Serena vd., 2005; Johnson-Lopes, 2008) ve yaş, tarihsel dönem vb. farklılıklardan (Costanza-Finkelstein, 2015) kaynaklanmaktadır. X kuşağının daha bireyci (Twenge, 2010), y kuşağının daha sorgulayıcı (Chester, 2003), z kuşağının ise dijital çağa dönük çok yönlü bireyler 
olduğu belirlenmiştir. Bu bakımdan her kuşağın kendisine has özelliklerinin bilinmesi kuşakların birbirini daha iyi anlamasına yardımcı olabilmektedir.

İncelenen eserlerin 12 'sinde büyük ebeveynden toruna bilgi aktarımının (\%4.56) gerçekleştiği tespit edilmiştir. Brock ve Barnard (1999) aile üyeleri arasında sözel ve sözel olmayan mesajlarla bilgi alışverişinin gerçekleştiğini ifade etmiştir. Lahaye, Pourtois ve Desmet (2011) çalışmasında ise nesiller arası bilgi aktarımında yeni kuşağın aile büyüğünden edindiği bilginin bir kısmını muhafaza ettiği, bir kısmını da dönüştürerek yeniden üretebildiği tespitine yer verilmiştir.

İncelenen eserlerin 9'unda hayal gücü eğitimine dair unsura rastlanmıştır. Araştırma bulgularını destekleyecek biçimde Broinowski (2002) de okul öncesi dönemde hayal gücü eğitimi verilmesinin çocukların yaratıcı düşünme becerilerini geliştirdiğini tespit etmiştir.

İncelenen eserlerin 12'sinde dede ve nine karakterlerinin "problem çözme" aktarımına rastlanmış̧ır. Torunlar, içinden çıkılamayacak bir sorun yaşadıklarında (Gemici Dedem, Çetin Ceviz vb.) büyük ebeveynler, tecrübelerinden yararlanarak çocukların sorunlarını çözmelerine yardımcı olmaktadır. Araştırma bulgularıyla paralel olarak Kılıç ve Yılmaz (2016) çalışmasında yaşlıların, yaşanılan bir problemi tecrübelerinden yararlanarak çabucak çözdüklerini belirtmiştir. Özyürek vd. de (2018) öğrenilebilen becerilerden olan problem çözme becerisinin geliştirilmesinde çocukla etkileşimde bulunan yetişkinlerin model alındığını tespit etmiştir.

Araştırma kapsamında incelenen eserlerin 5'inde nine ve dede karakterlerinin çocuklara olumsuz örnek teşkil edebilecek (yalan söyleme, kavgacılık, cinsiyetçilik vb.) aktarımlarının (DB, ÇÇ vb.) olduğu tespit edilmiştir. Büyük ebeveynlerin çocuklara kötü örnek teşkil edecek davranışlara ve tutumlara başvurması yeni nesillerin yanlış örneklerle karşılaşmasına ve bu davranış ve tutum kalıplarını içselleştirip davranışa dönüştürmesine neden olabileceğinden bu hususların üzerinde ehemmiyetle durulması gerekmektedir.

19 ana kategori ve 44 alt birim bağlamında incelenen 15 çağdaş çocuk kitabında unsur çeşitliliği açısından "Dedemin Uçan Dairesi”, toplam unsur oranı aç1sından ise "Ninemin Yemekleri Dedemin oyuncakları isimli eserler en fazla ögeye sahiptir. Büyük ebeveyn-torun arasındaki iletişimin ise büyük oranda olumlu ol- 
duğu (14 eser) sonucuna ulaşılmıştır. Ancak kitapların genelinde nine ve dedelerin sunuluş biçimlerinin çeşitlilik göstermekten uzak olduğu, belirli alanlarda öbekleşmenin var olduğu ve bazı kategorilerde çok az (tarih şuuru) aktarımın var olduğu bazılarında ise hiç (vatan sevgisi) aktarımın bulunmadığı belirlenmiş, mevcut aktarımların ise yeterli nicelikte ve nitelikte olmadığ 1 tespit edilmiştir. Eserlerde dede ve nine karakterlerinin aktarımlarının çocuğun gelişimine, toplumsallaşmasına, kültürlenmesine, erdem ve faziletleri edinmesine, kuşaklar aras1 paylaşım sürecinin sağlıklı bir şekilde gerçekleşebilmesine vb. katkı sağlayabilecek şekilde dengeli bir dağılım göstermemesi ve birkaç alanda odaklanılması bir eksiklik olarak görülmüştür.

\section{Öneriler}

Araştırma kapsamına uygun olarak çocuk kitaplarında aile büyüklerinin sunuluş biçimlerine dair şu öneriler sunulabilir:

Yayınevleri, çocukların ihtiyaçlarını dikkate alarak büyük ebeveyn-torun ilişkisi ve aktarımını merkeze alan ve çocuklar için doğru rol model oluşturabilecek aile büyüklerini barındıran eserlerin yayımlanması için çalışmalar yapabilir.

Anne ve babalar; çocuklarının köksüzleşmemesi adına onları nitelikli eserlerle buluşturulabilir ve böyle eserlerin hazırlanması için talepkâr olarak gerekli hassasiyeti gösterebilir.

Türkçe ve diğer branşlar için hazırlanan ders kitaplarında büyük ebeveyntorun ilişki ve aktarımına katkı sağlayacak nitelikli metinlere yer verilebilir.

Öğretmenler, öğrencilerin gelişimine katkı sağlayacak eserleri tavsiye edebilir, okul ve sınıf kütüphanelerinde bu kitaplara yer verilmesi için gayret gösterebilir ve zararlı gördüğü eserlere karşı gerekli uyarıları yapabilir.

Öğretim programı geliştiricileri aile büyükleri ile torunların etkileşimini arttıracak faaliyetler ve materyaller oluşturulması için gerekli adımları atabilir. 


\section{Kaynakça}

Akyol, Hayati (1997). "Kelime öğretimi”, Milli Eğitim, 134, 46-47.

Alperen, M. Ahsen (2013). Sosya-Ekonomik Statü Açısından Yaşlıların Aile İlişkileri: Ankara Keçiören Örneği, Konya: Selçuk Üniversitesi Sosyal Bilimler Enstitüsü, Yüksek lisans Tezi.

Altan, Selen ve Tarhan, Sinem (2018). "Büyükanneden Toruna: Yaşam Boyu Öğrenme Sürecinde Değer ve Beceri Aktarımı”, Bartın Üniversitesi Ĕ̆itim Araştırmaları Dergisi, 2 (1), 26-42.

Aluş, Yadigâr (2015). "Kültürel ve Toplumsal Gerçekliğimiz Açısından Aile Anlayışlarının ve Türk Ailesinin Değerlendirmesi”, PESA Uluslararası Sosyal Araştırmalar Dergisi, 1 (1), 15-24.

Alver, Köksal (2005). “Çocuk ve Edebiyat”, Hece Aylık Edebiyat Dergisi Çocuk Edebiyatı Özel Sayısı, (104-105), 307-308.

Apaydın, Halil (2001). “Aile İçi İletişimin Çocuğun Dinsel Gelişimine Etkisi”, Ondokuz Mayıs Üniversitesi İlahiyat Fakültesi Dergisi, (12-13), 320-337.

Appelbaum, Steven., Serena, Maria. and Shapiro, Barbara (2005). "Generation 'X' And The Boomers: An Analysis Of Realities And Myths”, Management Research News, 28 (1), $1-33$.

Arıcı, Ali Fuat (2016). "Erken Çocukluk Dil Gelişiminde Ailenin Rolü”, Türkiye Eğitim Dergisi, 1 (1), 66-78.

Arpac1, Fatma ve Bekar, Aydan (2013). "Çocukların Büyük Ebeveynleri ile Etkileşimlerine İlişkin Görüşleri”, Selçuk Üniversitesi Sosyal Bilimler Enstitüsü Dergisi, (29), 11-29.

Ay, M. Emin (2015). Çocuklarımıza Allah’ı Nasıl Anlatalım? (33.Baskı). İstanbul: Timaş Yayınları.

Aybey, Salih (2018). “Ailenin Dini Değerleri Aktarmadaki Rolü ve Bu Süreçte Dikkat Edilmesi Gereken İlkeler”, İnsan ve Toplum Bilimleri Araştırmaları Dergisi, 7(2), 544-560.

Beland, M. Robert and Mills, L. Terry (2001). "Positive Portrayal Of Grandparents In Current Children's Literature." Journal Of Family Issues, 22 (5), 639-651.

Brock, W. Gregory and Barnard, P. Charles (1999). Procedures In Marriage and Family Therapy. Boston: Allyn and Bacon.

Broinowski, Ian (2002).Toward Creativity In Early Childhood Education. www.library. unisa. edu.au. (Erişim Tarihi:03.04.2019)

Büyüköztürk, Şener. Kılıç Çakmak, Ebru. Akgün, Ö. Erkan., Karadeniz, Şirin., ve Demirel, Funda (2016). Bilimsel Araştırma Yöntemleri. (21. Bask1). Ankara: Pegem Akademi Yayınc1lik.

Canatan, Ayşe (2008). "Toplumsal Değerler ve Yaşl1lar", Yaşlı Sorunları Araştırma Dergisi, (1), 62-71. 
Ceyhan, Nesîme (2009). "Çocuklara Tarih Şuuru Kazandırmada Tarihî Hikâyelerden Yararlanma Üzerine Bir Deneme", 1st International Syposium on Sustainable Deveopment (June 9-10 2009). Sarajevo: International Burch University.

Chester, Eric (2002). Employing Generation Why? Katy, TX: Tucker House Books. Chu, C. Y. Cyrus. Xie, Yu. and Yu, R. Ruoh (2011). "Coresidence With Elderly Parents: A Comparative Study Of Southeast China and Taiwan”, Journal Of Marriage and Family, 73 (1), 120-135.

Costanza, P. David and Finkelstein, M. Lisa (2015). "Generationally Based Differences In The Workplace: Is There A There There?", Industrial and Organizational Psychology: Perspectives On Science and Practice, 8 (3), 1-27.

Crawford, A.Patricia and Bhattacharya, Shakira (2014). "Grand Images: Exploring Images Of Grandparents In Picture Books", Journal Of Research In Childhood Education, 28(1), 128-144.

Çiftçi, Taner ve Dikmenli, Yurdal (2016). "Üniversite Öğrencilerinin Vatan Algısı ve Geçmişe Dönük Değişimi”, International Periodical For The Languages, Literature and History Of Turkish Or Turkic. 11 (3), 847-860.

Demiriz, Serap ve Arpacı, Fatma (2016). "Okul Öncesi Dönem Çocuklarının Büyük Ebeveynleri Hakkındaki Görüşlerinin İncelenmesi”, Çankırı Karatekin Üniversitesi Sosyal Bilimler Enstitüsü Dergisi, 7 (1), 707-726.

Dench, G. and Ogg, J. (2002). Grandparenting In Britain: A Baseline Study. London: Institute Of Community Studies.

Doğan, Abide (2005). "Cahit Uçuk’un Macera Romanları”, Hacettepe Üniversitesi Türkiyat Araştırmaları (HÜTAD), (3), 21-50.

Dunifon, Rachel and Bajracharya, Ashish (2012). "The Role Of Grandparents In The Lives Of Youth”, Journal Of Family, 33 (9), 1168-1194.

Engin, Ali., Osman (2013). Dede ve Nineden Uzak Yetişen Çocuk İletişim Sorunu Yaşıyor. Milliyet Gazetesi, https://www.milliyet.com.tr/cocuk/dede-ve-nineden-uzakyetisencocuk-iletisim-sorunu-yasiyor-1683753 (Erişim Tarihi: 21.03.2019)

Eşitti, Şakir (2016). “Çizgi Filmlerde Küresel ve Yerel Kültürün İnşası: Caillou ve Pepee Örneği”, Karadeniz Uluslararası Bilimsel Dergi, 32 (32), 125-144.

Fenwick, Geof and Morrison, Angela (2001). "Images Of Grandparents In Young Children's Picture Books In The United Kingdom”, New Review Of Children's Literature and Librarianship, 7 (1), 127-145.

Frrat, Hatice (2018). "Grandparent-Grandchild Relationships In Turkish Children's Novels", Universal Journal Of Educational Research, 6 (10), 2047-2060.

Geçgel, Hulusi ve Ak, Nilsu (2007). “Aziz Nesin'in Öykülerinde Çocuk ve Eğitim Teması”, Dokuz Eylül Üniversitesi Bucak Eğitim Fakültesi Dergisi. (22), 115-124.

Göğüş, Beşir (1978). Orta Dereceli Okullarımızda Türkçe ve Yazın Eğitimi. Ankara: Gül Yayınevi. 
Greenblat, Evelyn and Ochiltree, Gay (1993). Use and Choice Of Child Care (AIFS Early Childhood Study, No. 4). Melbourne: Australian Institute Of Family Studies.

Güler, Sibel (2010). “Türk Mutfak Kültürü ve Yeme İçme Alışkanlıkları”, Dumlupınar Üniversitesi Sosyal Bilimler Dergisi, (26), 25-30.

Gürses, İbrahim ve Kılavuz, M.,Akif (2016). Kuşakların Ahlâkî Değerleri Birlikte Öğrenmesi: Kohlberg'in Ahlâkî Gelişim Kuramı Açısından Bir Değerlendirme. Uludă̆ Üniversitesi İlahiyat Fakültesi Dergisi, 25 (1), 97-117.

Hazer, Oya (2011). "Ergenlerin Büyük Ebeveynlerinden Beklentilerini Etkileyen Faktörlerin İncelenmesi”, Hacettepe Üniversitesi Sosyolojik Araştırmalar E- Dergisi, 1-22.

Hazer, Oya (2012). "Büyük Ebeveynlerinin Ergenler Tarafından Algılanan Özelliklerini Etkileyen Faktörlerin İncelenmesi”, EFD/JFL Edebiyat Fakültesi Dergisi, 29 (1), 123-141.

Hillman, James (1999). The Force Of Character. Sydney: Random House.

İlhan, M. Emir (2017). "Hatırlamadan Hayale Tanpınar Estetiği ve Sözlü Kültür”, Selçuk Üniversitesi Türkiyat Araştırmaları Dergisi, (42), 184-199.

Janelli, M. Linda (1988). “Depictions Of Grandparents In Children's Literatüre”, Journal Educational Gerontology, 14 (3), 193-202.

Johnson, A. James and Lopes, John (2008). "The Intergenerationalworkforce, Revisited" Organization Development Journal, (26), 31-36.

Kıbrıs, İbrahim (2016). “Okuyucularına Bakış Açısı Kazandırma Yönüyle Ayla Çınaroğlu’nun Çocuk Öykü ve Romanları”, Abant İzzet Baysal Üniversitesi Eğitim Fakültesi Dergisi, 9 (1).

Kılıç, B., Sittık ve Yılmaz, Oğuzhan (2016). "Beyaz Bulut Dergisindeki Kurgusal Metinlerde Karakterler Yoluyla Verilen İletiler”, (Ed. M. Günyüz, B., V. Yıldız, T. Şimşek), IlI. Uluslararası Çocuk ve Gençlik Edebiyatı Sempozyumu bildiriler kitabı içinde (ss. 457-470). İstanbul: Çocuk ve Gençlik Edebiyatı YazarlarıBirliği.

Kı1ıç, N. Pınar (2018). "Kuşaklararası İletişim: Üniversite Öğrencilerinin Yaşlılarla İletişim Biçimleri”, Uluslararası Sosyal Araştırmalar Dergisi. 11 (55), 849-860.

Kornhaber, Arthur (1996). Contemporary Grandparenting, Sage Publications, Thousand Oaks, CA.

Koşkunlu, Yasemin (2008). Muzaffer İzgü’nün Anneannemin Akıl Almaz Maceraları Serisindeki Aile Kavramının Çocuk Gelişimi Açısından Değerlendirilmesi. İzmir: Dokuz Eylül Üniversitesi, Eğitim Bilimleri Enstitüsü, (yüksek lisans tezi).

Lahaye, Willy., Pourtois, J. Pierre and Desmet, Huguette (2011). Kuşaktan Kuşağa Aktarım. Çocuklarımız Çocuklarını Nasıl Ĕgitiyor?. (Çev. Z. C. Özatalay), (1. Baskı), İstanbul: İletişim Yayınları.

Lussier, Gretchen. Deater-Deckard, Kirby. Dunn, Judy and Davies, Lisa (2002). "Support Across Two Generations: Children's Closeness To Grandparents Following Parental Divorce and Remarriage", Journal Of Family Psychology, 16 (3), 363-376.

Maraşl1, Ahmet (2012). Okumayı Sevdirme Yolları. İstanbul: Timaş Yayınları. Merriam, B. Sha- 
ran (1988). Case Study Research In Education: A Qualitative Approach. San Francisco: Jossey-Bass.

NICHD, Early Child Care Research Network (1996). "Characteristics Of Infant Child Care: Factors Contributing To Positive Caregiving”, Early Childhood Research Quarterly, (11), 269-306.

Norman, N. MarilY and Jordan, C. Joy (2015). Targeting Life Skills In 4-H Gainsville: 4-H Youth Development, Uf/Ifas Extension, Institute Of Food And Agricultural Sciences, University Of Florida. Retrieved From University Of Florida IFAS. http://edis.ifas. ufl.edu/pdffiles/4H/4H24200.pdf. (Erişim Tarihi: 04.03.2019)

Onuk Ö. Eda (2013). “İlkokul Çağı Çocuklarının Söz Varlığının Gelişiminde Masallar”, Sakarya University Journal Of Education, 3 (1), 21-31.

Önkaş, Nilgün (2016). “Türkçe Ders Kitapları Metinlerinde Tarih Bilinci”, (Ed. A. Kiriş Avaroğulları), IV. Uluslararası Tarih Eğitimi Sempozyumu bildiriler kitabı içinde (ss. 572576). Muğla: Muğla Sitkı Koçman Üniversitesi.

Özdemir, Emin (1980). Türk ve Dünya Edebiyatı. Ankara: Ankara Üniversitesi Siyasal Bilgiler Fakültesi Yayınları.

Öztürk, Zehra (2003). "Eğitim Tarihimizde Okuma Toplantılarının Yeri ve Okunan Kitaplar", Değerler Eğitimi Dergisi, 1 (3), 131-155.

Özyürek, Arzu. Çetin, Asya. Şahin Derya. Yıldırım, Rukiye ve Evirgen, Neslihan (2018). "Okul Öncesi Dönem Çocuklarda Problem Çözme Becerilerinin Bazı Değişkenler Açısından İncelenmesi”, Uluslararası Erken Çocukluk Eğitimi Çalışmaları Dergisi, 3 (2), 32-41.

Patton, M. Quinn (2014). Nitel Araştırma ve Değerlendirme Yöntemleri. (Çev. Ed. M. Bütün. S. B. Demir.), (3.baskı) Ankara: Pegem Akademi Yayıncılık.

Poduval Jayita and Poduval Murali (2009). "Working Mothers: How Much Working, How Much Mothers and Where Is The Womanhood?" Mens Sana Monographs, 7(1), 6379, doi: 10.4103/0973-1229.41799 PMID:21836780.

Rousseau, Jean Jacques (2014). Emile (Bir Çocuk Büyüyor) (16. Bask1). İstanbul: Selis Kitaplar.

Sallabaş, M., Eyyüp (2012) “Ömer Seyfettin Hikâyelerinin Türkçe Öğretiminde Değer Aktar1mı Bakımından İncelenmesi”, Mustafa Kemal Üniversitesi Sosyal Bilimler Enstitüsü Dergisi, 59-68.

Sever, Sedat (2008). Çocuk ve Edebiyat. İzmir: Tudem Yayınları.

Smith, K. Peter (2005). “Grandparents and Grandchildren”, The Pscyhologist, 18 (11), 684687.

Soriano, Marc (1979). "Hakkettikleri Kitaplardan Yoksun Çocuklar”, UNESCO’dan Görüş Dergisi, (3).

Taşdemir, Edip ve Coşkun, V. Mustafa (2016). "Türkçe Ders Kitaplarında Tarihî Değerler”, (Ed. A. Kiriş Avaroğulları), IV. Uluslararası Tarih Eğitimi Sempozyumu bildiriler kitabr içinde (ss. 320-330). Muğla: Muğla Sitkı Koçman Üniversitesi. 
Topçu, Nurettin (2016). Türkiye’nin Maarif Davası (23. Bask1). İstanbul: Dergah Yayınları.

Tuğrul, Belma. Ertürk, H. Gözde. Özen Altınkaynak, Şenay ve Güneş, Gökhan (2014). “Oyunun Üç Kuşaktaki Değişimi”, The Journal Of Academic Social Science Studie, (27), $1-16$.

Türkmen, Nilgün (2013). "Çizgi Filmlerin Kültür Aktarımındaki Rolü ve Pepee”, Cumhuriyet Üniversitesi Edebiyat Fakültesi Sosyal Bilimler Dergisi, 36 (2), 139- 158.

Twenge, M. Jean (2010). "A Review Of Empirical Evidence On Generational Differences In Work Attitudes”, Journal Of Business Psychology, 25 ( 2), 201-210.

Uğur, Sinem Burcu (2018). "Torun Bakım Faaliyetinin Bakım Sağlayıcı Büyükannelerin Sağlık Durumları Üzerindeki Etkisi”, Mediterranean Journal Of Humanities Dergisi, VIII (1), 399-415.

Utaş Akhan, Latife. ve Batmaz, Makbule (2011). 0-6 Yaş Grubu Çocuğu Olan Çalışan Annelerin Çocuk Bakımı ile İlgili Karşılaştıkları Sorunların ve Sorun Çözme Yaklaşımlarının İncelenmesi. Florence Nightingale Hemşirelik Dergisi, 19 (3), 161-167.

Yavuzer, Haluk (2018). Ana-Baba ve Çocuk (28. Baskı). İstanbul: Remzi Kitabevi. Yıldırım, Ali ve Şimşek, Hasan (2016). Sosyal Bilimlerde Nitel Araştırma Yöntemleri. (10. Bask1). Ankara: Seçkin Yayınları.

Yılmaz, Aliye (2012). “Çocuk Eğitiminde Masalın Yeri (Binbir Gece Masalları Örneği)”, Süleyman Demirel Üniversitesi Fen-Edebiyat Fakültesi Sosyal Bilimler Dergisi, (25), 299-306.

Y1lmaz, Mehmet ve Duman, Tayyip (2017). “TRT Çocuk Dergisi’nde Milli Bir Değer Olarak Vatan - Vatanseverlik değeri”. İnsan ve Toplum Bilimleri Araştırmaları Dergisi, 7 (2), 639-657.

Yusuf Has Hacip (2003). Kutadgu Bilig. Ankara: TTK Yayınlar 